\title{
STUDIES ON FOWL CHOLERA
}

\section{THE TOXINS OF BACILLUS AVISEPTICUS ${ }^{1}$

\author{
PHILIP HADLEY
}

Received for publication June 15, 1917

In presenting the results of his very suggestive studies on the agglutination of bacteria in vivo, Dr. Bull (1916) makes the following statement:

From table 1 it is seen that bouillon cultures of Bacillus avisepticus are highly toxic for rabbits, $0.5 \mathrm{cc}$. of culture per kilo causing acute death. The intoxication is largely due to a toxin, since 1 cc. per kilo of body weight of a bacteria-free filtrate from a twenty-four hour culture causes acute death.

and again:

These results especially emphasize the significance of agglutinins and opsonins in the mechanism of natural resistance to infection, since Bacillus avisepticus produces a powerful toxin and is still incapable of causing a septicemia of any consequence in the presence of these antibodies.

In view of the difficulty of reconciling these conclusions with studies conducted by other investigators upon Bacillus avisepticus, as well as with observations made by the present writer (Hadley 1912, 1914a, 1914b, 1917) in studies on infection and resistance in fowl cholera, it seems desirable to bring into relief the somewhat extraordinary nature of the statements made by Dr. Bull with reference to toxin-production by virulent cultures of the fowl cholera bacteria. This is perhaps especially desirable at this time in view of the many current misconceptions regarding

${ }^{1}$ Contribution 233 from the Agricultural Experiment Station of the Rhode Island State College. 
the nature and biological features of the bacterial species in question

In a series of classic papers which appear to have attracted less attention than they deserve among American students of immunological problems, Edmund Weil (1905a, 1905b, 1907a, $1907 \mathrm{~b}, 1908$ ) following the steps of Bail, has presented the clearest evidence as to the elements favoring infection which characterize the activity of the bacteria of the fowl cholera group. An analysis of the situation as based upon his studies and those of his collaborators (Weil and Braun, 1909) may briefly be summarized as follows:

1. Rabbits, inoculated in the pleural cavity with virulent fowl cholera cultures produce an exudate which harbors substances favoring infection-the aggressins.

2. These aggressins, which are manifestly equivalent to the virulins of Rosenow and to the antiphagines of Tchistovitch and Yourevitch, possess in high degree the property of furthering infection. Treated animals die with a sub-lethal dose of virus while control animals resist ten times that dose.

3 . The infection-furthering property of the exudate does not lie in poisonous substances, since animals easily tolerate 12 cc. or eight times the dose necessary to determine a fatal issue when administered together with a non-lethal dose of virus.

4. The results cannot be due to an inactivating influence in the opsonic sense, since leukocytes (whether in immune or normal animals) manifest no, or slight, phagocytosis either in vitro or in vivo.

5. Toxicity and aggressivity are not identical; toxicity is most noteworthy in organisms which are not highly aggressive; and the most aggressive organisms are non-toxic. $B$. avisepticus, the causative agent in cholera of fowls, is the most aggressive organism that has been studied.

Weil's tests, devised to show whether toxins can be held responsible for the highly fatal results following inoculation with fowl cholera virus, are elaborately planned and (so far as one may judge) carefully executed. Pasteur's observation on the toxicity of the concentrated filtrates of $B$. avisepticus has never been 
confirmed under conditions in which it was clearly shown that no bacteria were present in the filtrate. Stang, moreover, was able to inject 20 cc. of concentrated filtrate without producing an infection, or signs of poisoning.

Weil concludes that one cannot demonstrate the slightest toxicity against the most susceptible animals (like the rabbit) in the case of fowl cholera. He pertinently inquires why a toxin-neutralization if present in immune animals should diminish the unlimited development of the bacteria. B. avisepticus shows characters sharply opposed to those of toxin-forming bacteria which never develop in great numbers in the body (diphtheria, tetanus, dysentery).

Another line of investigation which demonstrates the lack of extracellular toxins in the case of $B$. avisepticus is found in the experiment of Citron and Pütz (1907) who employed serum extracts and water-extracts of virulent bacterial cultures (artificial aggressins as opposed to natural aggressins of Weil). With these artificial aggressins the authors mentioned inoculated rabbits with the aim of furthering infection, or of producing immunity. The method did not in either case prove so successful as the method of Weil, involving pleural exudates, but the point for our present consideration is that the experiments conducted were such as to demonstrate the total lack of either exotoxins or endotoxins in the materials used for injections. The inoculated animals invariably remained in good health up to the time of infection with the active virus.

Other evidence showing the absence of toxins in the case of B. avisepticus is supplied indirectly by the studies of Weil and Braun (1909). Weil (1905b) had already shown that his method of inoculation with sterile pleural exudates was not only sufficient to protect animals against infection, but that the serum of such animals possessed protective power. The question naturally arose regarding the nature of the protective substances in such serum. Weil and Braun attempted to ascertain whether the protection was due to bactericidal substances. Animals were accordingly inoculated with serum which had been "treated" (absorbed) with fowl cholera bacteria, and survived infection. 
When the treated serum was tested for its bactericidal properties it was found that they had quite disappeared. Untreated serum still showed a slight growth-inhibiting power. The authors were therefore led to conclude that bactericidal antibodies cannot be considered in the protective action since they can be separated from such serum without causing the degree of protection to be diminished. In a similar manner Weil was able to show later that old immune serum might retain its bactericidal properties after it had lost all protective power.

The same authors demonstrated by detailed experiments that there is no opsonic action in fowl cholera immune serum. It was clearly shown that there was no phagocytosis of the fowl cholera bacteria in either normal or immunized animals. Sulima (1909) on the contrary, showed that some phagocytosis took place in immune animals but that it was not marked. It is obvious that in dealing with such small organisms as the bacteria of fowl cholera $(0.3$ to $0.5 \mu)$ one must use suitable methods of staining, and much care in examining the leukocytes for evidences of phagocytosis.

In the work of Huntemüller (1906) also there is good evidence of the lack of toxin-production by $B$. avisepticus. One phase of this writer's investigations involved the injection into rabbits of large amounts of bacterial filtrates in order to ascertain whether protective substances could be washed out of the cells. This was not found to be the case; but the point of present interest lies in the fact that the injection of the filtrates produced no ill effect as they certainly would have done if the organisms used had been capable of elaborating so powerful an exotoxin as Dr. Bull's statements imply.

Taken as a whole, the results of studies on infection and immunity in fowl cholera, although appearing to demonstrate that the protective function of fowl cholera immune serum does not rest upon the action of opsonins, nor upon bacteriolytic or bactericidal components (thus, by elimination, suggesting an antitoxic immunity), have failed to reveal the activity of any agent that can properly be regarded as a toxin, either intra- or extra-cellular. $\therefore$ Within the past few years the present writer (Hadley and 
Amison, 1911, Hadley, 1912, 1914a, 1914b) has devoted some attention to the problems of infection and resistance in the organisms of the hemorrhagic septicemia group. Use has been made of a highly virulent culture (strain 48) of B. avisepticus. The lethal dose of this culture for rabbits has frequently stood at $0.000,000,000,001$ cc. of a forty-eight-hour broth culture. Gallagher (1917) in recent experiments, in which he employed the same culture as the infective agent to test the immunizing power of the writer's Culture 52, as well as of certain strains of cattle, sheep and swine septicemia; used the strain in amounts of $0.000,000,001$ cc. with regularly successful infections. Such a strain should be well adapted for testing out the question of toxinproduction by $B$. avisepticus.

\section{EXPERIMENTAL}

In studies involving the attempt to immunize rabbits and pigeons with killed cultures of strain 48 , not yet reported, the writer has had occasion to administer large doses of killed broth culture. The following is a protocol:

Eight rabbits (923-931) each received subcutaneously on October $17,1912,1$ cc. of a forty-eight hour broth culture of strain 48 killed by heating at $63^{\circ} \mathrm{C}$. for thirty minutes; no illness resulted. Dose repeated on November 21 and again on December 5 ; no result.

On December 20, 1912, all the animals, together with two controls, were infected by inoculation with $0.01 \mathrm{cc}$. of forty-eight hour broth culture of strain 48. The controls and all but two of the principals died in fourteen to forty hours.

From the above test it may be concluded that the cultures killed at a temperature usually regarded as too low to destroy in toto extracellular toxins, if present, showed no toxicity for rabbits in the amounts used; furthermore that they failed in all but two instances to afford protection against infection with living culture.

Tests were also performed on pigeons, which are highly susceptible to intramuscular inoculation with the fowl cholera virus.

Six pigeons were inoculated subcutaneously, at intervals of 
seven to ten days with forty-eight-hour broth eultures of strain 48, killed by heating at $63^{\circ}$ for one-half hour. ${ }^{2}$

\begin{tabular}{|c|c|c|c|c|c|c|c|c|c|}
\hline \multicolumn{7}{|c|}{ PROTECTIVE INOCULATIONB } & \multicolumn{3}{|c|}{ INFBCHON WITH CULTERE 48. MARCB 17} \\
\hline \multirow{2}{*}{$\begin{array}{l}\text { INOOCO- } \\
\text { LATTON } \\
\text { INCORD }\end{array}$} & \multicolumn{5}{|c|}{ Dates and amounts } & \multirow{2}{*}{ 㻤 } & \multirow{2}{*}{ 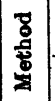 } & \multicolumn{2}{|c|}{ Result } \\
\hline & $2-3$ & $2-10$ & $2-17$ & $2-24$ & 3-3 & & & Date of Death & Peried \\
\hline 1240 & 1.0 & 2.0 & 2.0 & 2.0 & 2.0 & $\mathbf{s}$ & $\mathbf{s}$ & March 23 & Six days \\
\hline 1241 & 1.0 & 2.0 & 2.0 & 2.0 & 2.0 & $\mathbf{M}$ & $\mathbf{s}$ & March 28 & Eleven days \\
\hline 1242 & 1.0 & 2.0 & 2.0 & 2.0 & & 8 & $\mathbf{s}$ & March 18 & One day \\
\hline $1243^{*}$ & 1.0 & 2.0 & 2.0 & 2.0 & & $\mathbf{M}$ & $\mathbf{S}$ & April 4* & Survived \\
\hline 1244 & 1.0 & 2.0 & & & & $\mathbf{S}$ & $\mathbf{S}$ & March 18 & One day \\
\hline 1245 & 1.0 & 2.0 & & & & $\mathbf{M}$ & $\mathbf{S}$ & March 23 & Six days \\
\hline 1276 & & & & & & & $\mathbf{s}$ & March 18 & One day \\
\hline 1277 & & & & & & & $\mathbf{M}$ & March 18 & One day \\
\hline
\end{tabular}

$S$, subcutaneous (in the neck).

$M$, intramuscular (in the breast muscle).

* Reinforced with 0.000,01 cc. culture 48, March 30.

No reactions followed the immunizing inoculations with killed cultures. Two weeks after the last immunizing dose all the principals together with two controls were infected with $0.000,01$ cc. of culture 48 , as shown in the table, and with the results indicated. ${ }^{3}$

These protocols are similar to many others on record and indicate how free the $B$. avisepticus cultures were from anything that could be regarded as bacterial toxins. One can readily imagine the results that would follow had $B$. diphtheriae or some other toxic culture been used in these experiments in place of the fowl cholera bacterium

The instances mentioned above involved the use of killed cultures and the doses were not administered intravenously as was the case in Dr. Bull's tests on rabbits and dogs in which he obtained results that suggested acute intoxication. In order

2 In this particular test, in order to obtain a more concentrased suspension of bacteria, the cultures were centrifuged and two-thirds of the supernatant medium poured off. The sediment was re-suspended in the remaining one-third and injected.

3hese data will be presented at a later date in connection with the subject of immunization by means of killed cultures. 
to reproduce more faithfully the experimental conditions under which he worked the writer inoculated intravenously two rabbits with 1 cc. per kilo body weight of a forty-eight-hour killed broth culture of the highly virulent strain 48 killed by heating at $62^{\circ}$ for 20 minutes. The results are indicated in the accompanying table.

\begin{tabular}{|c|c|c|c|c|c|}
\hline \multirow{2}{*}{$\begin{array}{l}\text { INOCU- } \\
\text { LATION } \\
\text { RICORD }\end{array}$} & \multirow{2}{*}{ WEIGHT } & \multicolumn{3}{|c|}{ INOCULATION (INTRAVENOUS) } & \multirow{2}{*}{ BIBTORY OF ANIMAL } \\
\hline & & Time & Culture & Amount & \\
\hline & grams & & & $c c$. & \\
\hline $1584 \mathrm{~A}$ & 950 & $\begin{array}{c}\text { May 1, } 4 \\
\text { p.m. }\end{array}$ & $\begin{array}{l}\text { Killed at } \\
62^{\circ} \mathrm{C} \text {. for } \\
20 \text { min- } \\
\text { utes }\end{array}$ & 1.0 & $\begin{array}{l}5.00 \text { p.m., sick } \\
11.00 \text { p.m., no change. } \\
7.00 \text { a.m., May } 2 \text {, quiet, does not } \\
\text { eat } \\
7.00 \text { a.m., May } 3 \text {, condition in- } \\
\text { proved }\end{array}$ \\
\hline $1585 \mathrm{~A}$ & 880 & $\begin{array}{c}\text { May 1, } 4 \\
\text { p.m. }\end{array}$ & Living & 0.9 & $\begin{array}{l}5.00 \text { p.m., sick } \\
11.00 \text { p.m., very weak, breathing } \\
\text { with difficulty } \\
7.00 \text { a.m., dead; general septi- } \\
\text { cemia }\end{array}$ \\
\hline
\end{tabular}

From the data presented in the tabulation it is apparent that the intravenous injection of killed culture produced no indications of strong toxicity; moreover, that inoculation with a relatively large amount of living culture produced fatal results only after a period of fourteen hours, indicating no strong toxic action in the unmodified virus.

In addition to the tests mentioned above, another experiment may be cited which demonstrates even more conclusively the absence of a strong extra-cellular toxin derived from a highly virulent culture of $B$. avisepticus growing in broth culture.

A rabbit was inoculated by the intra-abdominal route with 0.001 cc. of a broth culture of strain 48 and died in fourteen hours. The culture was regained from the heart's blood and plated. A colony was subcultured into flasks of chicken broth. One of these was grown at $37^{\circ} \mathrm{C}$. for forty-eight hours and passed through a Berkefeld N-candle under suction. The filtrate was tested for sterility as follows: Ten 0.1 cc. samples of filtrate were trans- 
ferred to tubes of chicken broth and incubated at $37^{\circ} \mathrm{C}$. for ninety-six hours. No growth appeared at the end of that time. In the meantime the remaining filtrate was divided into three portions: portion a was placed in the ice-box; portion $b$ was incubated for twenty-four hours at $37^{\circ} \mathrm{C}$., and portion $\mathrm{c}$ was heated at $62^{\circ} \mathrm{C}$. for twenty minutes. The incubated filtrate showed no growth. It was intended to inject all three portions into rabbits, but, owing to an accident, only the ice-box filtrate and the heated filtrate were employed for rabbits. These were injected intravenously in amounts of 1 cc. as shown in the accompanying table. Of the incubator filtrate $1 \mathrm{cc}$. was injected intravenously into an adult hen:

\begin{tabular}{|c|c|c|c|c|}
\hline $\begin{array}{l}\text { INOCULATION } \\
\text { RECORD }\end{array}$ & WEIGHT & FILTRATE & DATE & HISTORY OF ANIMAL \\
\hline $\begin{array}{l}1580 \\
1581 \\
411 \mathrm{H}\end{array}$ & $\begin{array}{l}\text { grams } \\
2100 \\
1390\end{array}$ & $\begin{array}{l}\text { Heated } \\
\text { Ice-box } \\
\text { Incubator }\end{array}$ & $\begin{array}{l}\text { April 5, } 4 \text { p.m. } \\
\text { April } 5 \\
\text { April } 5\end{array}$ & $\begin{array}{l}\text { Remains normal } \\
\text { Remains normal } \\
\text { Remains normal }\end{array}$ \\
\hline
\end{tabular}

From these results there is no evidence of a toxic filtrate from the growth of $B$. avisepticus.

The tests described above were made with filtrate from a fortyeight-hour broth culture. Assuming that sufficient time might not have been given for toxin-formation, the second flask was incubated for four days at $37^{\circ} \mathrm{C}$., and the culture passed through a Berkefeld N-candle under suction. The fifteen-minute filtrate was tested for sterility by the inoculation of five tubes of chicken broth with $0.1 \mathrm{cc}$. samples. No growth resulted after forty-eight hours' incubation. The remaining filtrate was divided into two lots. One was placed in the incubator and the other in the icebox for about twenty-four hours, until used. Intravenous inoculations were made as shown in the following tabulation: 


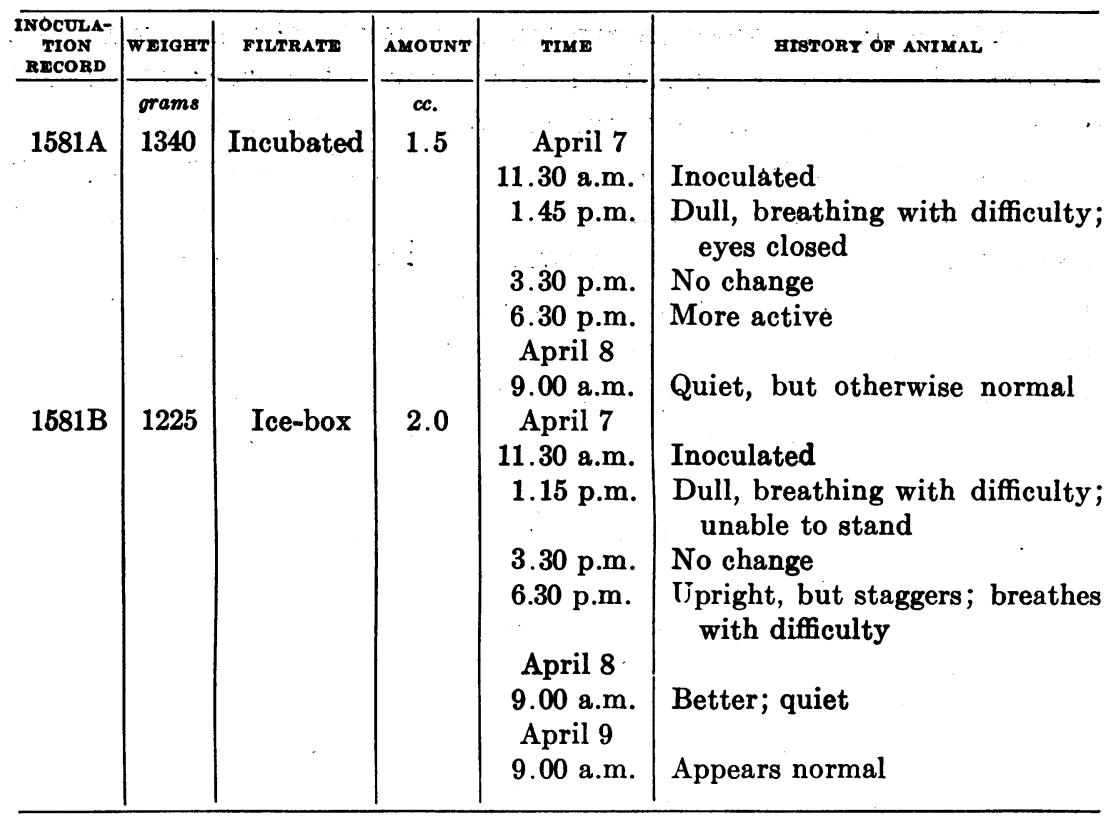

In the results of this test it appears that a reaction closely simulating an anaphylactic shock resulted from the inoculation of the second filtrate. The result was not fatal, however, and it may be questioned whether it was due to the presence of an exotoxin or to some other factor at present unrecognized.

In view, however, of the discrepancy between the first and second tests, a third experiment was undertaken in which use was made of a still larger amount of filtrate from a six-day chicken broth culture passed through a Berkefeld N-candle. The filtrate was tested for sterility, and divided into two portions, one of which was incubated over night and the other placed in the ice-box. A slight haziness developed in the incubator tubes and subcultures were made in chicken broth. These, however, remained sterile. A 1314-gram rabbit was accordingly inoculated intravenously with 1.5 cc. of the incubator filtrate. No sign of illness followed within the following twenty-four hours during which the animal was under observation. 
As a final test, in order to explain, if possible, the discrepancies between Bull's results and those of the present writer, it seemed desirable to repeat the experiment with the same culture used by Bull. Fortunately, as a result of the careful records kept by the laboratory of the Curator of Public Health, at the American Museum of Natural History, it was possible to locate the culture used by Bull, who had in the meantime discarded his strain, and to obtain a subculture, together with a brief history of organism. This seemed especially desirable in view of the many errors that are made in the recognition of the organism of the authentic fowl cholera. It can scarcely be doubted that the majority of the cultures so labelled, that may be obtained from any laboratory, are not $B$. avisepticus.

Upon receipt of the culture it was plated and subcultured in chicken agar. Flasks of chicken broth were inoculated and incubated for forty-eight hours at $37^{\circ} \mathrm{C}$. One of the cultures was then passed through a Berkefeld $\mathrm{N}$-candle under suction and this filtrate tested for sterility. The filtrate was then divided into two portions, one of which was inoculated at $37^{\circ} \mathrm{C}$. over night as a final test of sterility; the other kept in the ice-box. The following morning, all evidences having pointed toward the sterility of the filtrate, a 1.5 cc. sample was injected intravenously into a 1375-gram rabbit, which died in less than three hours with symptoms of intoxication.

Another rabbit of 1347 grams was inoculated intravenously with 0.7 cc. of a twenty-four-hour chicken broth culture of Dr. Bull's strain and no ill effects resulted. Apparently 1.5 cc. of a forty-eight-hour culture-filtrate contained a lethal dose of toxin, while $0.7 \mathrm{cc}$. of a twenty-four-hour culture did not. This is suggestive of an endotoxin rather than an exotoxin. To demonstrate this further, a forty-eight-hour culture of Dr. Bull's strain was shaken for one-half hour, incubated at room temperature for fortyeight hours and shaken again for three hours. It was then passed through a Berkefeld N-candle and the filtrate tested for sterility by subcultures. Of the sterile filtrate 0.5 cc. was then injected into the ear vein of a 1000 -zram rabbit. One hour after the 
injection the rabbit showed definite symptoms of intoxication and died in about six hours.

The tests reported in the previous pages were sufficient to demonstrate a total lack of toxicity in the culture or filtrates of B. avisepticus (strain 48) employed, but to show the presence of a strong toxic substance in the filtrate of forty-eight-hour cultures of the organism used by Dr. Bull. The contrasts may be summarized as follows:

\begin{tabular}{|c|c|c|}
\hline ORGANISM & FILTRATE & CULTURE \\
\hline $\begin{array}{l}\text { B. avisepticus (strain no. } \\
\text { 48) }\end{array}$ & $\begin{array}{l}\text { Non-toxic in amounts of } \\
1 \text { cc. per kilo of body- } \\
\text { weight }\end{array}$ & $\begin{array}{l}\text { Highly infectious in } \\
\text { amounts of (at least) } \\
0.000,000,001 \text { cc. for } \\
\text { rabbit of any weight, } \\
\text { producing death in four- } \\
\text { teen hours }\end{array}$ \\
\hline Dr. Bull's culture & $\begin{array}{l}\text { Toxic in amounts of } 0.5 \\
\text { to } 1 \text { cc. per kilo of body } \\
\text { weight. Fatal in two } \\
\text { to six hours }\end{array}$ & $\begin{array}{l}\text { Small amounts of twenty- } \\
\text { four hour culture harm- } \\
\text { less.* }\end{array}$ \\
\hline
\end{tabular}

* May perhaps become lethal after several passages through rabbits.

In view of these discrepancies, it seemed desirable to examine culturally the strain employed by Dr. Bull. It was therefore submitted to the usual cultural and biochemical tests; and in addition was tested for its agglutinative reactions with a number of immune sera, including those of B. avisepticus and Bact. gallinarum (fowl typhoid). These tests will now be described.

Morphological, cultural and biochemical features of Dr. Bull's strain. Slides prepared from twenty-four-hour chicken agar cultures and stained with gentian violet revealed a short plump rod, having an average size of 0.7 by $0.45 \mu$. a maximum size of 1.2 by $0.5 \mu$, and a minimum size of 0.4 by $0.3 \mu$. The ends of the rods were rounded and many of the shorter rods resembled cocci. Pairs of rods were common; chains of three seldom seen; filaments occasionally. Peripheral staining was observed. 
The culture grew well on chicken agar; resembled in all respects growth of Bact. pullorum or B. typhosus. In broth there was a fair clouding at the end of twenty-four hours.

No gas was formed in glucose, sucrose or lactose (Smith tubes). Titration of culture from the open arm of these cultures, and of cultures in other sugar broths (in plain tubes) at the end of five days gave the following results:

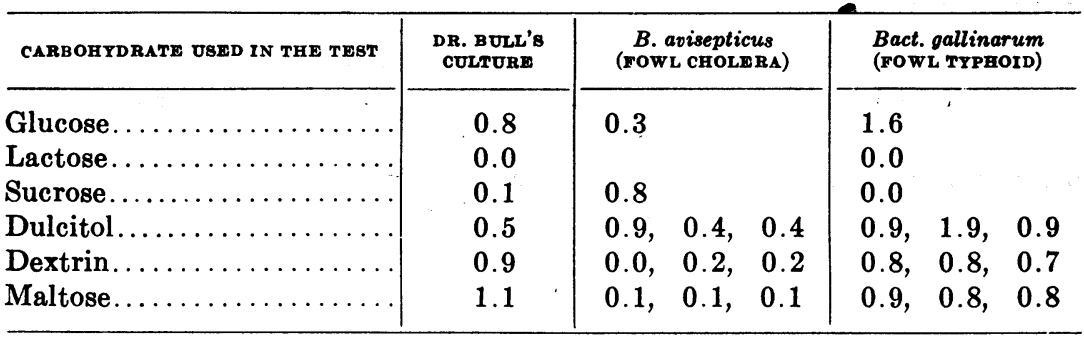

Litmus milk inoculated with one loopful of a twenty-four-hour broth culture showed a slight acidity in twelve hours at $37^{\circ} \mathrm{C}$. This increased slightly for the next twelve to twenty-four hours but after thirty-six to forty-eight hours there was a tendency to return to neutral. The cream ring, however, began to turn blue ${ }^{4}$ about twenty-four hours after the inoculation of the tubes and the color steadily increased so to as give a blueness of grade $2^{5}$ before the body of the milk had returned to neutral. Neutralization occurred on the sixth day after inoculation. On the seventh the body of the milk as well as the cream ring was slightly alkaline and on the eighth distinctly alkaline (grade 1). Grade 3 alkaline was attained on the thirtieth day.

Without entering into further details regarding the biochemical reactions, a sufficient number of data have been presented to indicate clearly that the culture with which Dr. Bull worked was not $B$. avisepticus in the sense that this is the causative agent in

\footnotetext{
- It is interesting to note that in alkalining cultures such as $B$. pullorum, $B$. gallinarum and the paratyphoids $A$ and $B$, the alkalinity may be shown in the cream ring for some days before the color of the body of the milk has even returned to neutral, and many days before the body of the milk becomes alkaline.

- See Hadley (1917).
} 
fowl cholera and a member of the hemorrhagic septicemia group. B. avisepticus does not ferment most of the carbohydrates ordinarily used in bacteriological work; and it leaves litmus milk quite unchanged after a period of ninety days at $37^{\circ} \mathrm{C}$.

Agglutination tests. In view of the fact that fowl cholera immune serum seldom if ever agglutinates completely (in vitro) its homologous antigen in dilutions greater than $1: 160$, the specific agglutination test is obviously of slight value in testing a questionable strain. It is necessary to demonstrate an affinity or lack of affinity with other immune sera. Since the majority of so-called fowl cholera cultures maintained in the laboratories of this country are not B. avisepticus but Bact. gallinarum (E. Klein), or some other member of the colon-typhoid intermediates, Dr. Bull's culture was first tested against sera immune to the bacillus of fowl typhoid. Since the laboratory collection of immunized animals contained rabbits immune to two fowl typhoid strains obtained from Dr. Theobald Smith, these, among others, were employed for the tests with results as shown in the following table.

From a study of the agglutination features as presented in the table it appears that there was present a satisfactory agglutination affinity between all of the sera immune to the fowl typhoid strains (Bact.gallinarum) $\left(115,116,102 \mathrm{~A}^{6}\right.$ and $\left.118^{6}\right)$ and Dr. Bull's culture, but none with Bact. avisepticus antigen. Moreover, that serum immune to $B$. avisepticus while agglutinating its homologous antigen at $\frac{\mathrm{C}}{40}, \frac{4}{80}, \frac{2}{160}$, failed to agglutinate Dr. Bull's culture in any significant dilution. 


\begin{tabular}{|c|c|c|c|c|c|c|c|c|c|c|}
\hline \multicolumn{2}{|r|}{ SERUM AND ANTIGEN } & \multicolumn{8}{|c|}{ SERUM -DILUTIONB } & \multirow[b]{2}{*}{ DATE } \\
\hline 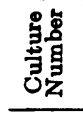 & Designation & $\frac{1}{40}$ & $\frac{1}{80}$ & $-\frac{1}{160}$ & $\frac{1}{320}$ & $\frac{1}{640}$ & $\frac{1}{1,280}$ & $\overline{\frac{1}{2,560}} \mid$ & 형 & \\
\hline 15 & $\begin{array}{l}\text { Fowl typhoid, vs. } \\
\text { Homolog. antigen....... } \\
\text { B. arisept. antigen...... } \\
\text { Bull. cult. antigen...... } \\
\text { Hog cholera antigen.... }\end{array}$ & $\begin{array}{l}\mathrm{C} \\
0 \\
\mathrm{C} \\
\mathrm{T}\end{array}$ & $\begin{array}{l}\mathrm{C} \\
0 \\
\mathrm{C} \\
0\end{array}$ & $\begin{array}{l}\mathrm{C} \\
0 \\
\mathrm{C} \\
0\end{array}$ & $\begin{array}{l}\mathrm{C} \\
0 \\
\mathrm{C} \\
0\end{array}$ & $\begin{array}{l}\mathrm{C} \\
0 \\
\mathrm{C} \\
0\end{array}$ & \begin{tabular}{l|}
$\mathrm{C}$ \\
0 \\
- \\
-
\end{tabular} & $\begin{array}{l}4 \\
- \\
- \\
-\end{array}$ & $\begin{array}{l}\mathrm{T} \\
0 \\
0 \\
0\end{array}$ & $\mid \begin{array}{r}12-22-16 \\
1-19-17 \\
3-30-17 \\
2-16-17\end{array}$ \\
\hline 116 & \begin{tabular}{|l|} 
Fowl typhoid, vs. \\
Homolog. antigen....... \\
B. avisept. antigen ...... \\
Bull. cult. antigen...... \\
Human typhoid antigen.
\end{tabular} & $\begin{array}{l}\mathrm{C} \\
0 \\
\mathrm{C} \\
1\end{array}$ & $\begin{array}{l}\mathrm{C} \\
0 \\
\mathrm{C} \\
\mathrm{T}\end{array}$ & $\begin{array}{l}\mathrm{C} \\
0 \\
4 \\
0\end{array}$ & $\begin{array}{l}4 \\
0 \\
2 \\
0\end{array}$ & $\begin{array}{l}2 \\
0 \\
1 \\
0\end{array}$ & $\begin{array}{l}\mathrm{T} \\
0 \\
- \\
0\end{array}$ & $\begin{array}{l}- \\
- \\
-\end{array}$ & $\begin{array}{l}\mathrm{T} \\
0 \\
0 \\
0\end{array}$ & $\begin{array}{l}4-20-17 \\
1-20-17 \\
4-20-17 \\
3-2-17\end{array}$ \\
\hline $102 A^{6}$ & $\begin{array}{l}\text { Fowl typhoid (?), vs. } \\
\text { Homolog. antigen....... } \\
\text { B. avisept. antigen...... } \\
\text { Bull. cult. antigen...... } \\
\text { Human typhoid antigen. }\end{array}$ & $\begin{array}{l}\mathrm{C} \\
2 \\
- \\
0\end{array}$ & $\begin{array}{l}\mathrm{C} \\
1 \\
\mathrm{C} \\
0\end{array}$ & $\begin{array}{l}\mathrm{C} \\
0 \\
\mathrm{C} \\
0\end{array}$ & $\begin{array}{l}\mathrm{C} \\
0 \\
\mathrm{C} \\
0\end{array}$ & $\begin{array}{l}4 \\
0 \\
\mathrm{C} \\
0\end{array}$ & $\begin{array}{l}\underline{2} \\
- \\
- \\
-\end{array}$ & $\begin{array}{l}\mathrm{T} \\
- \\
- \\
-\end{array}$ & $\begin{array}{l}0 \\
0 \\
0 \\
0\end{array}$ & $\begin{array}{r}7-31-16 \\
11-7-15 \\
3-12-17 \\
3-12-17\end{array}$ \\
\hline $118^{6}$ & $\begin{array}{l}\text { Fowl typhoid, vs. } \\
\text { Homolog. antigen....... } \\
\text { B. avisept. antigen...... } \\
\text { Bull. cult. antigen ...... } \\
\text { Bact. pullorum antigen... }\end{array}$ & $\begin{array}{l}\mathrm{C} \\
0 \\
\mathrm{C} \\
\mathrm{C}\end{array}$ & $\begin{array}{l}\mathrm{C} \\
0 \\
\mathrm{C} \\
\mathrm{C}\end{array}$ & \begin{tabular}{l|}
$\mathrm{C}$ \\
0 \\
$\mathrm{C}$ \\
$\mathrm{C}$
\end{tabular} & \begin{tabular}{l|l}
$\mathrm{C}$ \\
0 \\
$\mathrm{C}$ \\
$\mathrm{C}$
\end{tabular} & $\begin{array}{l}\mathrm{C} \\
0 \\
\mathrm{C} \\
\mathrm{C}\end{array}$ & $\begin{array}{l}4 \\
- \\
- \\
-\end{array}$ & $\begin{array}{l}3 \\
- \\
- \\
-\end{array}$ & $\begin{array}{l}0 \\
0 \\
0 \\
0\end{array}$ & $\begin{array}{l}4-23-17 \\
4-23-17 \\
4-23-17 \\
4-23-17\end{array}$ \\
\hline Mxd. & $\begin{array}{l}\text { Bact. pullorum, vs. } \\
\text { Homolog. antigen..... } \\
\text { B. avisept. antigen.... } \\
\text { Bull. cult. antigen.... } \\
\text { Fowl typh. antigen.... }\end{array}$ & $\begin{array}{l}\mathrm{C} \\
0 \\
1 \\
\mathrm{C}\end{array}$ & $\begin{array}{l}\mathrm{C} \\
0 \\
\mathrm{~T} \\
\mathrm{C}\end{array}$ & \begin{tabular}{l|}
$\mathrm{C}$ \\
0 \\
0 \\
$\mathrm{C}$
\end{tabular} & \begin{tabular}{l|l}
$\mathrm{C}$ \\
0 \\
0 \\
$\mathrm{C}$
\end{tabular} & $\begin{array}{l}\mathrm{C} \\
0 \\
0 \\
4\end{array}$ & $\begin{array}{l}- \\
\overline{-} \\
\overline{0}\end{array}$ & $\begin{array}{l}- \\
- \\
-\end{array}$ & $\begin{array}{l}0 \\
0 \\
0 \\
0\end{array}$ & $\begin{array}{l}3-3-17 \\
1-22-17 \\
3-10-17 \\
3-3-17\end{array}$ \\
\hline 48,52 & $\begin{array}{l}\text { B. avisepticus, vs. } \\
\text { Homolog. antigen....... } \\
\text { Bact. pull. antigen...... } \\
\text { Bull. cult. antigen...... } \\
\text { Fowl typh. antigen...... }\end{array}$ & $\begin{array}{l}\mathrm{C} \\
0 \\
0 \\
0\end{array}$ & $\begin{array}{l}4 \\
0 \\
0 \\
0\end{array}$ & $\begin{array}{l}2 \\
0 \\
0 \\
0\end{array}$ & $\begin{array}{l}\mathrm{T} \\
0 \\
0 \\
0\end{array}$ & $\begin{array}{l}0 \\
0 \\
- \\
-\end{array}$ & $\begin{array}{l}0 \\
0 \\
- \\
-\end{array}$ & $\begin{array}{l}- \\
- \\
- \\
-\end{array}$ & $\begin{array}{l}\mathrm{T} \\
0 \\
\mathrm{~T} \\
0\end{array}$ & $\begin{array}{l}4-20-17 \\
3-26-17 \\
4-20-17 \\
3-26-17\end{array}$ \\
\hline & 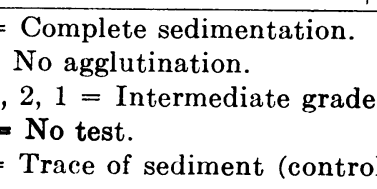 & & & & & & & & & \\
\hline
\end{tabular}

${ }^{6}$ Probably Bact. pullorum (Note at time of correcting proof). 


\section{CONCLUSIONS}

These results of the agglutination tests appear to substantiate the results of the cultural tests in demonstrating that Dr. Bull's culture was a strain of the fowl typhoid bacterium and not a representative of the fowl cholera or hemorrhagic septicemia group. The facts that cultures of the fowl cholera bacterium are non-toxic, and that they are not opsonized into phagocytosis, therefore remain uncontroverted so far as Dr. Bull's experiments are concerned. Indeed Tchistovitch (1909) appears to have demonstrated that, in the case of the actual fowl cholera organism, serum from the dog did not assist the rabbit leukocytes to ingest the fowl cholera organisms. Notwithstanding this circumstance, however, Dr. Bull's study of phagocytosis in reference to the culture used by him, if properly interpreted, adds much to our knowledge of the toxicity, opsonins and phagocytosis of one of the most interesting and slightly studied types of the colontyphoid intermediates.

\section{REFERENCES}

BULL 1916 J. Exper. M., 24, 25-33.

Citron and Pütz 1907 Ztschr. f. Hyg. u. Infektionskrankh., 66, 145-174.

Gallagher 1917 J. Am. Vet. Ass., 60, 708.

Hadley and Amison 1911 R. I. Agr. Exper. Sta., Bull. 146.

Hadley 1912 R. I. Agr. Exper. Sta. Bull. 150.

Hadley 1914a R. I. Agr. Exper. Sta. Bull. 157.

Hadley .1914b R. I. Agr. Exper. Sta. Bull. 159.

HADLeY 1917 J. Bact. 2, (73, 263).

Huntemüller 1906 Centralbl. f. Bakteriol., Abt. i, Orig. 42, 170.

Sulrman 1909 Ann. de l'Inst. Pasteur, 23, 911-920.

Tschistovitch 1909 Ann. de l'Inst. Pasteur, 23, 834.

WeIL 1905a Arch. f. Hyg. 52, 413-432.

WeIL 1905b Arch. f. Hyg. 54, 149-183.

W.eIL 1907a Ztschr. f. Hyg. u. Infektionskrankh., 56, 509-515.

WeIL 1907b Arch. f. Hyg., 61, 293-323.

WeIL 1908 Arch. f. Hyg. 65-66, 81-106.

Weil and BradN 1909 Fol. Serologica. 2, 151. 